Vol 1 Issue 1 (2018)

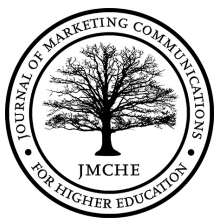

\title{
Correlating the Relationship Between U.S. News \& World Report Rankings and Social Media Efficiency of the Top 10 Ranked Private Universities at the State Level (Massachusetts), the United States and the World (U.S. News \& World Report, 2019)
}

\author{
Patrick R. Goncalves M.S. Boston College
}

\section{Introduction}

This analysis will provide an overview of the top 10 ranked (U.S. News 2019) universities at the state level (Massachusetts), U.S. national, and the world. For each of the universities being analyzed in this study, data will be collected from university-centralized social media accounts. The following types of social media channels will be represented: Facebook, Twitter and Instagram. This study will report on the gross number of followers for each of these channels along with total institutional operating expense. The rationale is to establish a baseline for return on investment (ROI) pertaining to social media efficiency/influence by drawing correlations to current (2019) university rankings by U.S. News \& World Report. For the state level assessment, Massachusetts was selected simply based upon the proximity to where the study was being conducted, Boston College.

\section{U.S. News Ranking Methodology for National Universities}

U.S. News \& World Report defines a "national university" as:

...universities [that] offer a full range of undergraduate majors, as well as master's and doctoral degrees; many strongly emphasize research. The Carnegie classification defines them as Doctoral Universities (highest research activity), Doctoral Universities (higher research activity) and Doctoral Universities (moderate research activity) ${ }^{\text {. }}$

\footnotetext{
${ }^{1}$ Robert Morse, Matt Mason and Eric Brooks, "Best Colleges Ranking Category Definitions," http://www.usnews.com/education/best-colleges/articles/ranking-category-definitions, (October 1, 2018).
}

(C) 2018 Patrick R. Goncalves M.S.

This open access article is licensed under a Creative Commons Attribution: Non-Commercial license. DOI: JMCHE/vli102 
For the 2019 U.S. News Best College Rankings report (national universities), U.S. News enlisted a ranking methodology based on "ranking indicator weight". A total of 16 indicators ${ }^{2}$ were compiled into eight broader indicators. The following table illustrates the breakdown in indicator weights for the national university ranking ${ }^{3}$ :

\begin{tabular}{|c|c|}
\hline Ranking Indicator & $\begin{array}{l}\text { National Universities and } \\
\text { National Liberal Arts } \\
\text { Colleges Indicator Weight }\end{array}$ \\
\hline $\begin{array}{l}\text { - Average six-year graduation rate } \\
\text { - Average first-year student retention rate } \\
\text { Graduation and retention rates: }\end{array}$ & $\begin{array}{l}17.6 \% \\
4.4 \% \\
\mathbf{2 2} \% \text { (Total) }\end{array}$ \\
\hline $\begin{array}{l}\text { - Pell Grant graduation rates } \\
\text { - Pell Gant graduation rates compared with } \\
\text { Graduation and retention rates: }\end{array}$ & $\begin{array}{l}2.5 \% \\
2.5 \% \\
5 \%\end{array}$ \\
\hline Graduation rate performance: & $\mathbf{8 \%}$ \\
\hline $\begin{array}{l}\text { - Peer assessment survey } \\
\text { - High school counselors' ratings } \\
\text { Undergraduate academic reputation: }\end{array}$ & $\begin{array}{l}15 \% \\
5 \% \\
\mathbf{2 0} \%\end{array}$ \\
\hline $\begin{array}{l}\text { - Class size index } \\
\text { - Faculty compensation } \\
\text { - Percent faculty with terminal degree in their field } \\
\text { - Percent faculty that is full time } \\
\text { - Student-faculty ratio } \\
\text { Faculty resources for } \mathbf{2 0 1 7 - 2 0 1 8} \text { academic year: }\end{array}$ & $\begin{array}{l}8 \% \\
7 \% \\
3 \% \\
1 \% \\
1 \% \\
\mathbf{2 0 \%} \\
\end{array}$ \\
\hline $\begin{array}{l}\text { - Math and evidence-based reading and writing } \\
\text { portions of the SAT and the composite ACT scores } \\
\text { - High school class standing in top } 10 \% \\
\text { - High School class standing in top } 25 \% \\
\text { - Acceptance rate } \\
\text { Student selectivity for the fall } 2017 \text { entering } \\
\text { class: }\end{array}$ & $\begin{array}{l}7.75 \% \\
2.25 \% \\
0 \% \\
0 \% \\
\mathbf{1 0 \%}\end{array}$ \\
\hline Financial resources per student & $10 \%$ \\
\hline Average alumni giving rate & $5 \%$ \\
\hline Total & $100 \%$ \\
\hline
\end{tabular}

Please refer to Index A for definitions of each ranking indicator.

Outside of the "undergraduate academic reputation" ("peer assessment survey" $15 \%$ and "high school counselors' ratings" 5\%) there were no other measuring indicators chosen by U.S. News that considered any direct measure of brand equity, more specifically, online brand influence. The "peer assessment survey" reflected ratings provided by administrators (presidents, provosts, deans etc.) at peer institutions. The survey prompted administrators to rate undergraduate academic programs from a scale of 1 to 5, 1 being "marginal" and 5 being "distinguished." As a

\footnotetext{
2 Note: two indicators; "high School class standing in top 25\%" and "acceptance rate" were given a " 0 " weight

${ }^{3}$ Morse, Robert, and Eric Brooks. "Best Colleges Ranking Criteria and Weights,"

http://www.usnews.com/education/best-colleges/articles/ranking-criteria-and-weights, (October 1, 2018).
}

(C) 2018 Patrick R. Goncalves M.S.

This open access article is licensed under a Creative Commons Attribution: Non-Commercial license.

DOI: JMCHE/v1i102 
result, U.S. News elected high school guidance counselors due to their firsthand knowledge of colleges and universities.

About 12,200 guidance counselors from all 50 states were surveyed; high school counselors were also asked to rate undergraduate academic programs from a scale of 1 to 5,1 being "marginal" and 5 being "distinguished." The "undergraduate academic reputation" and its components are arguably influenced in part by a university's brand awareness, considering the fact that respondents form both the "peer assessment survey" and the "high school counselors' ratings" were asked to not evaluate schools that they were not familiar with. According to David Aaker's ${ }^{4}$ brand equity model, brand heritage plays an important role in fostering brand awareness. Aaker goes on to write:

Heritage brands (often the oldest brands in their respective categories) have the "Sincerity" characteristics of being honest, authentic, wholesome, trustworthy, friendly, familiar, caring and unassuming. ${ }^{5}$

As a result of Aaker's explanation of brand heritage and its connection to longevity, we can conclude that brand awareness is attributed to a greater degree with universities with a longstanding tradition.

\section{Calculating Social Media Efficiency}

For this analysis we will derive a quotient that will serve as a representation for measuring "social media efficiency". The factors for deriving this quotient, will include an institution's gross social media following for Facebook, Twitter and Instagram along with total operating expense. Total operating expense is made divisible by the gross number of social media followers (all three channels) to arrive at a cost per follower:

$$
\begin{aligned}
& \text { cost per } \\
& \text { follower }
\end{aligned}=\frac{\begin{array}{c}
\text { total operating } \\
\text { expense }
\end{array}}{\begin{array}{c}
\text { gross } \\
\text { followers }
\end{array}}
$$

\footnotetext{
${ }^{4}$ David Aaker is an American organizational theorist, consultant and Professor Emeritus at the University of California, Berkeley's Haas School of Business, a specialist in marketing with a focus on brand strategy.

5 Aaker David, Building Strong Brands (The Free Press, 1996), 231.
}

(C) 2018 Patrick R. Goncalves M.S.

This open access article is licensed under a Creative Commons Attribution: Non-Commercial license. DOI: JMCHE/vli102 


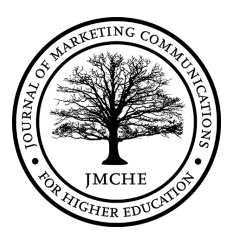

To reiterate, the reasoning for this is to establish a baseline in order to measure ROI as it relates to social media capital; social media capital in this instance being measured in number of followers. The universities being analyzed in this study all have slight variations in reporting nomenclature on their respective 2017 annual reports. For example, MIT's reporting nomenclature differs from Harvard's reporting nomenclature:

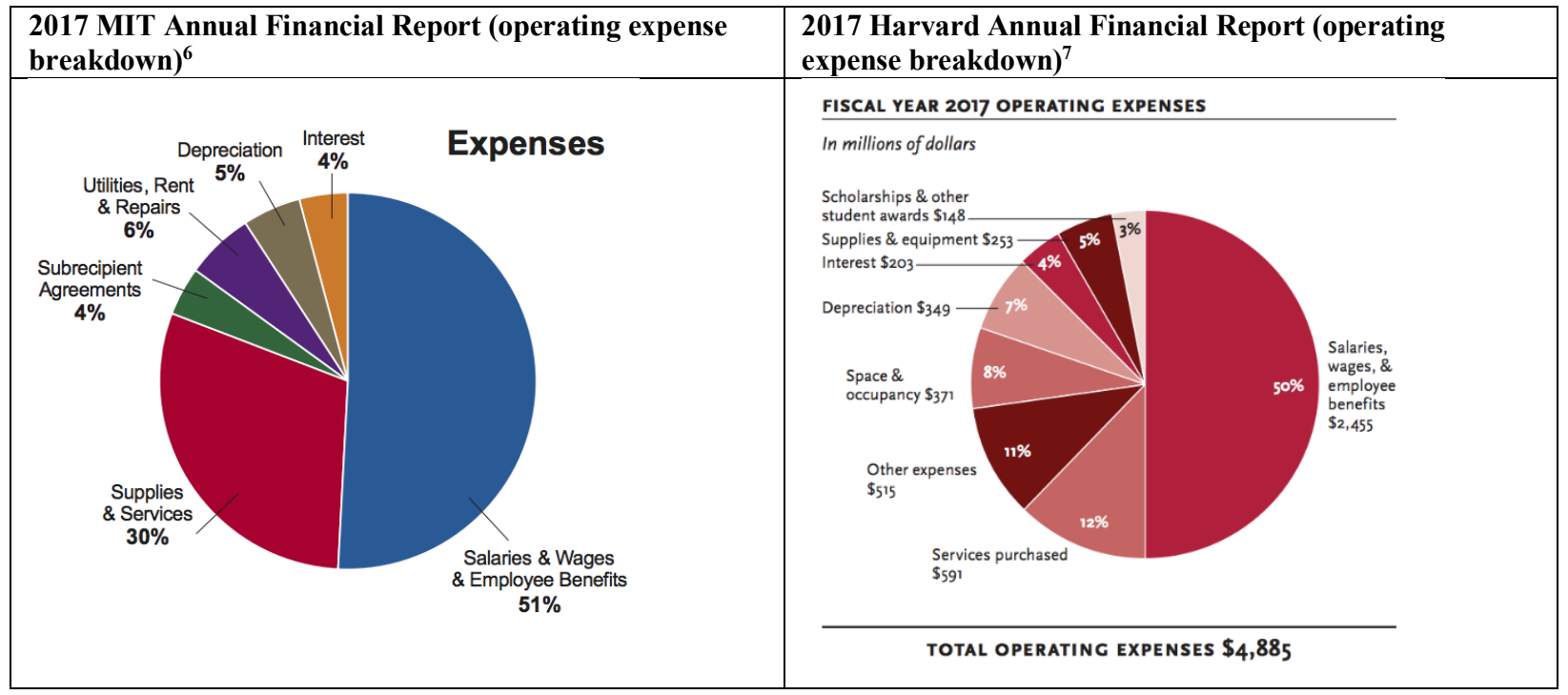

Figure 1. MIT Annual Financial Report (Left) and Harvard Annual Financial Report (Right)

Both MIT and Harvard share the same categories of salaries and wages and depreciation, however the remaining expenses are categorized differently in not only name but also number of categories. This adds a level of complexity when coming to an understanding of what the expenses are for marketing specifically. Arguably all marketing expenses could fall under "salaries, wages" and/or "services" however, there is no specific information available to clarify the category of "other expenses" found in some accounting reports for other universities; this creates too many unknowns in regards to expense specification. In conclusion, utilizing total operating expense as a factor for calculating "social media efficiency" is arguably the most impartial factor for establishing a baseline of measurement. As previously mentioned, "social media efficiency" will be determined by arriving at a cost per follower.

The factors will include institutional financial data (total operating expense) from fiscal year 2017, and gross followers from 2018 (retrieved on October). The one-year gap between the fiscal year (2017) and gross followers reporting date (October, 2018) represents an inconsistency that exists between institutions and their respective financial reporting calendars. For example,

${ }^{6}$ PricewaterhouseCoopers LLP, MIT REPORT OF THE TREASURER 2017: 5.

${ }^{7}$ PricewaterhouseCoopers LLP, FINANCIAL REPORT FISCAL YEAR 2017 (Harvard): 5.

(C) 2018 Patrick R. Goncalves M.S.

This open access article is licensed under a Creative Commons Attribution: Non-Commercial license.

DOI: JMCHE/v1i102 
UMass Amherst releases their annual report in December ${ }^{8}$, whereas other institutions, namely, Northeastern, WPI etc. release their financial statements at various times in the fall semester. Considering the timely nature of this study, financial data from UMass Amherst will not be retrieved in time to address the one-year gap. Therefore, to establish a baseline, operating expenses for 2017 will be used.

In addition, many, if not all, universities contain inter-department social media accounts. Totaling the number of followers for university wide accounts will present inconsistencies, as many of the same followers will follow several accounts operated by other departments within the university. Therefore, for this analysis, in order to establish a baseline, we will be reporting on only aggregate from university main accounts; which are accounts that are directly operated by the university's central marketing and communications office.

\section{Miscorrelation Factor}

In order to measure degrees of miscorrelation, this analysis will enlist a miscorrelation factor. The factor will be a basis of ' 1 ' for each miscorrelation. The miscorrelation factor is the difference between the two measurements, U.S. News ranking (national or global) and cost per follower. For example: if a university is ranked \#1 for U.S. News but by contrast, is ranked \#2 in terms of cost per follower, then a miscorrelation factor of 1 is applied. In addition, when applicable, miscorrelation factors will be negatively or positively correlated depending upon whether a university's position under the cost per follower category increases the university's ranking or decreases the university's ranking. Positive or negative miscorrelations will be delineated by a plus or minus sign after the miscorrelation factor.

The miscorrelation factors will be totaled for each assessment; Massachusetts, U.S. national and global. Totaling the miscorrelation factors will provide a baseline for measuring degrees of correlation in comparing each of the top 10 assessments. Note, total miscorrelation factors are not a summation of adding positive miscorrelation factors or subtracting negative miscorrelation factors; the total always represents the sum of factors and negative or positive signs do not play a role in their summation, therefore the total (summation) of miscorrelation factors will be delineated by a +/- sign. The greatest miscorrelation total for any particular assessment can be a maximum of 50. Based on this total, a miscorrelation percentage can be calculated which will be represented after the miscorrelation factor.

\footnotetext{
${ }^{8}$ Grant Thornton LLP, 2017 ANNUAL FINANCIAL REPORT (UMASS): 3.
}

(C) 2018 Patrick R. Goncalves M.S.

This open access article is licensed under a Creative Commons Attribution: Non-Commercial license. DOI: JMCHE/vli102 
Vol 1 Issue 1 (2018)

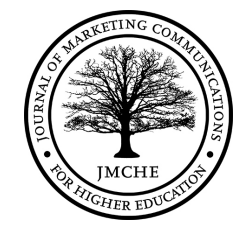

\section{Social Media Efficiency of the Top 10 National Universities in Massachusetts}

The following table provides data for the top 10 nationally ranked universities in Massachusetts (U.S. News \& World Report 2019)9.

\begin{tabular}{|c|c|c|c|c|c|c|c|c|}
\hline $\begin{array}{l}\text { Top } 10 \text { Nationally } \\
\text { Ranked Universities in } \\
\text { Massachusetts }\end{array}$ & $\begin{array}{l}\text { Total } \\
\text { Operating } \\
\text { Expense } \\
\text { (2017) } \\
\text { in thousands }\end{array}$ & Facebook & Twitter & Instagram & $\begin{array}{l}\text { Gross } \\
\text { Followers }\end{array}$ & $\begin{array}{l}\text { Cost Per } \\
\text { Followers }\end{array}$ & $\begin{array}{l}2019 \text { U.S. } \\
\text { News Ranking } \\
\text { (National } \\
\text { Universities) } \\
\text { *reported fall } \\
2018\end{array}$ & $\begin{array}{l}\text { Miscorrelation } \\
\text { Factor }\end{array}$ \\
\hline Harvard & $4,884,585^{10}$ & $5,251,654$ & $891 \mathrm{~K}$ & $917 \mathrm{~K}$ & $7,059,654$ & $\$ 691.90$ & 2 & 0 \\
\hline MIT & $3,464,024^{11}$ & $1,122,995$ & $969 \mathrm{~K}$ & $86.3 \mathrm{~K}$ & $2,178,295$ & $\$ 1590.24$ & 3 & 0 \\
\hline Tufts & $884,051^{12}$ & 50,338 & $41.8 \mathrm{~K}$ & $22.8 \mathrm{~K}$ & 114,938 & $\$ 7,691.54$ & 27 & 6- \\
\hline Brandeis & $342,860^{13}$ & 27,866 & $19.8 \mathrm{~K}$ & 7,329 & 54,995 & $\$ 6234.38$ & 35 & 4- \\
\hline Boston College & $798,831^{14}$ & 130,330 & $65.6 \mathrm{~K}$ & $77.8 \mathrm{~K}$ & 273,730 & $\$ 2918.31$ & 38 & $2+$ \\
\hline Boston University & $1,745,103^{15}$ & 313,002 & $93.6 \mathrm{~K}$ & $65.1 \mathrm{~K}$ & 471,702 & $\$ 3,699.58$ & 42 & $1+$ \\
\hline Northeastern University & $1,095,324^{16}$ & 107,970 & $37.8 \mathrm{~K}$ & $36.8 \mathrm{~K}$ & 182,570 & $\$ 5999.47$ & 44 & 0 \\
\hline WPI & $249,999^{17}$ & 26,335 & $14.3 \mathrm{~K}$ & 9,068 & 49,703 & $\$ 5029.85$ & 59 & $2+$ \\
\hline Clark University & $107,712^{18}$ & 18,988 & 8,166 & 6,655 & 33,809 & $\$ 3185.89$ & 66 & $5+$ \\
\hline UMASS Amherst & $3,163,322^{19}$ & 85,225 & $47.3 \mathrm{~K}$ & $26.1 \mathrm{~K}$ & 158,625 & $\$ 19,942.14$ & 70 & 0 \\
\hline $\begin{array}{l}\text { *social media data } \\
\text { retrieved on } 10 / 24 / 2018\end{array}$ & & & & & & & & $\begin{array}{l}20+/-(40 \% \\
\text { miscorelation) }\end{array}$ \\
\hline
\end{tabular}

Please refer to the References section for social media citation information

\section{Results}

The data for the top 10 nationally ranked universities in Massachusetts (U.S. News \& World Report 2019) presented Harvard, MIT, Northeastern and UMass as the only universities that were correlated (miscorrelation factor of 0 ) with their respective U.S. News ranking; Harvard ranking \#1, MIT ranking \#2, Northeastern University ranking \#7, and UMass Amherst ranking \#10 respectively. The greatest miscorrelation was by Tufts University with a factor of 6-. Clark University established the second largest miscorrelation, with a factor of 5+, increasing the university's social media efficiency ranking to \#4 for the top 10 U.S .News nationally ranked universities in Massachusetts. Other universities that were positively miscorrelated included; Boston College (2+), Boston University (1+) and Worcester Polytechnic Institute (2+). Brandies

\footnotetext{
9 “Best Colleges National University Rankings," U.S. News \& World Report, www.usnews.com/bestcolleges/rankings/national-universities, (October 24, 2018).

${ }^{10}$ PricewaterhouseCoopers LLP, FINANCIAL REPORT FISCAL YEAR 2017 (Harvard): 15.

11 PricewaterhouseCoopers LLP, MIT REPORT OF THE TREASURER 2017: 13.

12 PricewaterhouseCoopers LLP, Annual Financial Report 2017: 4

${ }^{13}$ KPMG LLP, Brandeis University: Financial Statements: 5

${ }^{14}$ PricewaterhouseCoopers LLP, Boston College: Consolidated Financial Statements May 31, 2018 and $2017: 6$

${ }^{15}$ KPMG LLP, Boston University Financial Statements June 30, 2017 and 2016: 5

${ }^{16}$ PricewaterhouseCoopers LLP, Northeastern University Consolidated Financial Statements June 30, 2017 and 2016: 6

${ }^{17}$ PricewaterhouseCoopers LLP, Worcester Polytechnic Institute Consolidated Financial Statements June 30,2017 and 2016: 6

${ }^{18}$ Grant Thornton LLP, Consolidated Financial Statements and Report of Independent Certified Public Accountants: Clark University May 31,2017 and 2016: 6

${ }^{19}$ Grant Thornton LLP, 2017 ANNUAL FINANCIAL REPORT (UMASS): 18
}

(C) 2018 Patrick R. Goncalves M.S.

This open access article is licensed under a Creative Commons Attribution: Non-Commercial license.

DOI: JMCHE/v1i102 
University was the only other university with a negative miscorrelation (-4). Overall $40 \%$ of the top 10 universities were correlated. The total miscorrelation factor for the top 10 cohort is $20+/-$ (40\% miscorrelation).

\section{Social Media Efficiency of the U.S. News \& World Report Top 10 National Universities in the United States}

The following table provides data for the top 10 nationally ranked universities in the United States (U.S. News \& World Report 2019) ${ }^{20}$ :

\begin{tabular}{|c|c|c|c|c|c|c|c|c|}
\hline $\begin{array}{l}\text { Top } 10 \text { Nationally } \\
\text { Ranked Universities in } \\
\text { Massachusetts }\end{array}$ & $\begin{array}{l}\text { Total } \\
\text { Operating } \\
\text { Expense } \\
\text { (2017) } \\
\text { in thousands }\end{array}$ & Facebook & Twitter & Instagram & $\begin{array}{l}\text { Gross } \\
\text { Followers }\end{array}$ & $\begin{array}{l}\text { Cost Per } \\
\text { Followers }\end{array}$ & $\begin{array}{l}2019 \text { U.S. News } \\
\text { Ranking (National } \\
\text { Universities) } \\
\text { *reported fall } \\
2018\end{array}$ & $\begin{array}{l}\text { Miscorrelation } \\
\text { Factor }\end{array}$ \\
\hline Princeton & $1,615,975^{21}$ & 566,493 & $329 \mathrm{~K}$ & $203 \mathrm{~K}$ & $1,098,493$ & $\$ 1,471.08$ & 1 & $1-$ \\
\hline Harvard & $4,884,585^{22}$ & $5,251,654$ & $891 \mathrm{~K}$ & $917 \mathrm{~K}$ & $7,059,654$ & $\$ 691.90$ & 2 & $1+$ \\
\hline Columbia & $4,384,914^{23}$ & 372,524 & $291 \mathrm{~K}$ & $159 \mathrm{~K}$ & 822,524 & $\$ 5,938.53$ & 3 (tie) & $3-$ \\
\hline MIT & $3,464,024^{24}$ & $1,122,995$ & $969 \mathrm{~K}$ & $86.3 \mathrm{~K}$ & $2,178,295$ & $\$ 1,590.24$ & 3 (tie) 4 & $1+$ \\
\hline University of Chicago & $4,327,652$ & 244,461 & $48.8 \mathrm{~K}$ & $65.6 \mathrm{~K}$ & 358,861 & $\$ 12,059$ & $3(\mathrm{tie}) 5$ & 3- \\
\hline Yale & $3,511,065^{25}$ & $1,309,215$ & $425 \mathrm{~K}$ & $247 \mathrm{~K}$ & $1,981,215$ & $\$ 1772.17$ & 3 (tie) 6 & $2+$ \\
\hline Stanford & $10,504,379^{26}$ & $1,257,690$ & $636 \mathrm{~K}$ & $418 \mathrm{~K}$ & $2,311,690$ & $\$ 4,544.02$ & 7 & $2+$ \\
\hline Duke & $5,802,959^{27}$ & 346,939 & $72 \mathrm{~K}$ & $110 \mathrm{~K}$ & 528,939 & $\$ 10,90.94$ & 8 (tie) & $1+$ \\
\hline U Penn & $8,896,729^{28}$ & 213,822 & $130 \mathrm{~K}$ & $96.4 \mathrm{~K}$ & 440,222 & $\$ 20,209.64$ & 8 (tie) 9 & $1-$ \\
\hline John Hopkins & $5,624,242^{29}$ & 182,204 & $75.5 \mathrm{~K}$ & $42.3 \mathrm{~K}$ & 300,004 & $\$ 18,747.22$ & 10 & $1+$ \\
\hline $\begin{array}{l}\text { *social media data } \\
\text { retrieved on } \\
10 / 29 / 2018\end{array}$ & & & & & & & & $\begin{array}{l}17+/-(34 \% \\
\text { miscorrelation) }\end{array}$ \\
\hline
\end{tabular}

Please refer to the References section for social media citation information

\section{Results}

The 2019 U.S. News rankings reported a 4-way tie for third place for the following universities (in order): Columbia, MIT, University of Chicago and Yale. The 2019 rankings also had a twoway tie for eighth and tenth place: Duke and UPenn for eighth, and John Hopkins and

\footnotetext{
20 “Best Colleges National University Rankings,” U.S. News \& World Report, www.usnews.com/bestcolleges/rankings/national-universities, (October 24, 2018).

${ }^{21}$ PricewaterhouseCoopers LLP, Report of the Treasurer 2016-2017 (Princeton): 10.

22 PricewaterhouseCoopers LLP, FINANCIAL REPORT FISCAL YEAR 2017 (Harvard): 15.

${ }^{23}$ PricewaterhouseCoopers LLP, The Trustees of Columbia University in the City of New York Consolidated Financial Statements June 30, 2018 and 2017: 4.

24 PricewaterhouseCoopers LLP, MIT REPORT OF THE TREASURER 2017: 13.

25 PricewaterhouseCoopers LLP, Financial Report 2017-2018 Yale University: 10.

${ }^{26}$ PricewaterhouseCoopers LLP, Stanford University Annual Financial Report August 31, 2017 and $2016: 28$.

${ }^{27}$ KPMG LLP, Duke University Financial Statements 2017/2018: 18.

28 PricewaterhouseCoopers LLP, Annual Financial Report 2016-2017: 39.

${ }^{29}$ KPMG LLP, THE JOHNS HOPKINS UNIVERSITY Consolidated Financial Statements and Independent Auditors' Reports Required by Title 2 U.S. Code of Federal Regulations Part 200, Uniform Administrative Requirements, Cost Principles, and Audit Requirements for Federal Awards, and Related Information Year Ended June 30, 2017 (With Independent Auditors' Report Thereon): 7.
}

(C) 2018 Patrick R. Goncalves M.S.

This open access article is licensed under a Creative Commons Attribution: Non-Commercial license.

DOI: JMCHE/vli102 


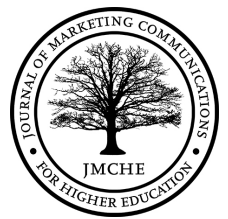

Northwestern for tenth. In contrast to the assessment of the top 10 universities in Massachusetts, $100 \%$ of the top 10 universities in the U.S. displayed a miscorrelation. In order to maintain an impartial basis for measurement, tied rankings will not be considered for this assessment of the top 10 nationally ranked universities in the U.S.; instead, the first 10 schools reported by the U.S. News will be given a ranking respective to their order.

Also, worth noting, U.S. News counts a tie ranking as a spot in the numerical order; for example, if two universities are tied for third the following university will be listed in fifth place instead of fourth. The data for the top 10 national universities in the U.S. reported no correlation; all the top 10 universities had a positive or negative miscorrelation of at least 1 . Columbia and the University of Chicago both reported the greatest miscorrelation of 3-. A total $60 \%$ of the top 10 universities displayed a miscorrelation factor of $1+/$-. In comparison to the state level assessment (Massachusetts), the U.S. national assessment displayed a greater overall correlation reporting a miscorrelation factor of $17+/-(34 \%$ miscorrelation $)$. 
Vol 1 Issue 1 (2018)

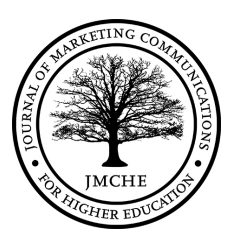

\section{U.S. News \& World Report Ranking Methodology for Global Universities}

The following table illustrates the breakdown in indicator weights for the U.S. News global university ranking ${ }^{30}$ :

\begin{tabular}{|l|l|}
\hline Ranking Indicator & Global Universities Indicator Weight \\
\hline Global research reputation & $12.5 \%$ \\
\hline Regional research reputation & $12.5 \%$ \\
\hline Publications & $10 \%$ \\
\hline Books & $2.5 \%$ \\
\hline Conferences & $2.5 \%$ \\
\hline Normalized citation impact & $10 \%$ \\
\hline Total citations & $7.5 \%$ \\
\hline $\begin{array}{l}\text { Number of publications that are among the } \\
10 \text { percent most cited }\end{array}$ & $12.5 \%$ \\
\hline $\begin{array}{l}\text { Percentage of total publications that are } \\
\text { among the 10 percent most cited }\end{array}$ & $10 \%$ \\
\hline International collaboration & $5 \%$ \\
\hline $\begin{array}{l}\text { Percentage of total publications with } \\
\text { international collaboration }\end{array}$ & $5 \%$ \\
\hline $\begin{array}{l}\text { Number of highly cited papers that are } \\
\text { among the top 1 percent most cited in their } \\
\text { respective field }\end{array}$ & $5 \%$ \\
\hline $\begin{array}{l}\text { Percentage of total publications that are } \\
\text { among the top 1 percent most highly cited } \\
\text { papers }\end{array}$ & $5 \%$ \\
\hline
\end{tabular}

Please refer to Index B for definitions each ranking indicator.

Much like the methodology used to calculate the U.S. News national university rankings the global ranking enlisted weighted ranking indicators that were split between reputation indicators and bibliometric ${ }^{31}$ indicators. As mentioned previously, reputation indicators are arguably influenced by a university's brand awareness and heritage.

${ }^{30}$ Morse, Robert, Alexis Krivian, and Elizabeth Martin, "How U.S. News Calculated the Best Global Universities Rankings," http://www.usnews.com/education/best-global-universities/articles/methodology, (October 29, 2018).

${ }^{31}$ Bibliometrics is statistical analysis of written publications, such as books or articles.

(C) 2018 Patrick R. Goncalves M.S.

This open access article is licensed under a Creative Commons Attribution: Non-Commercial license.

DOI: JMCHE/v1i102 


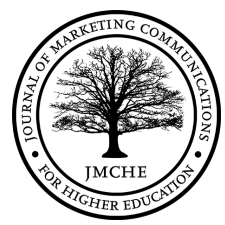

The calculating methodology for the global ranking included two reputation indicators; "global research reputation" and "regional research reputation." Both indicators counted as 12.5\% weight each, and reflected the data represented from the Academic Reputation Survey, a survey conducted by Clarivate Analytics. The survey called on respondents to rate universities at the field as well as the department level. The survey resulted in approximately 28,000 respondents which comprised the following job roles:

- 67 percent academic staff

- 16 percent research staff

- 7 percent senior institutional leaders

- 3 percent graduate/postgraduate students

- 7 percent other jobs and roles.

In contrast to the U.S. News national university reputation indicator ("undergraduate academic reputation") accounting for 20\% ("peer assessment survey" $15 \%$ and "high school counselors" ratings" 5\%); the U.S. News global reputation indicator weight counted for $25 \%$. It's fair to assume, that based on an increase reputation indicator, the global assessment should yield closer correlations between social media efficiency and U.S. News ranking, in comparison to the national and state level assessments. Also, worth noting, the Clarivate Analytics survey excluded respondents' nominations of their own institution or alma mater. Including only external nominations could also reinforce nominations for universities with greater brand awareness. ${ }^{32}$

\footnotetext{
${ }^{32}$ Morse, Robert, Alexis Krivian, and Elizabeth Martin, "How U.S. News Calculated the Best Global Universities
} Rankings," http://www.usnews.com/education/best-global-universities/articles/methodology, (October 29, 2018).

(C) 2018 Patrick R. Goncalves M.S.

This open access article is licensed under a Creative Commons Attribution: Non-Commercial license. DOI: JMCHE/v1i102 
Vol 1 Issue 1 (2018)

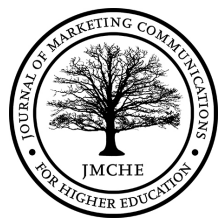

Social Media Efficiency of the U.S. News \& World Report Top 10 Global Universities The following table provides data for the top 10 ranked universities in world (U.S. News \& World Report 2019) $)^{33}$ :

\begin{tabular}{|c|c|c|c|c|c|c|c|c|}
\hline $\begin{array}{l}\text { Top } 10 \text { Nationally } \\
\text { Ranked } \\
\text { Universities in } \\
\text { Massachusetts }\end{array}$ & $\begin{array}{l}\text { Total Operating Expense } \\
\text { (2017) } \\
\text { in thousands }\end{array}$ & Facebook & Twitter & Instagram & $\begin{array}{l}\text { Gross } \\
\text { Followers }\end{array}$ & $\begin{array}{l}\text { Cost Per } \\
\text { Followers }\end{array}$ & $\begin{array}{l}2019 \text { U.S. } \\
\text { News Ranking } \\
\text { (Global } \\
\text { Universitie) } \\
\text { *reported fall } \\
\text { 2018 }\end{array}$ & $\begin{array}{l}\text { Miscorrelation } \\
\text { Factor }\end{array}$ \\
\hline Harvard & $4,884,585^{34}$ & $5,251,654$ & $891 \mathrm{~K}$ & $917 \mathrm{~K}$ & $7,059,654$ & $\$ 691.90$ & 1 & 1- \\
\hline MIT & $3,464,024^{35}$ & $1,122,995$ & $969 \mathrm{~K}$ & $86.3 \mathrm{~K}$ & $2,178,295$ & $\$ 1,590.24$ & 2 & $3-$ \\
\hline Stanford & $10,504,379^{36}$ & $1,257,690$ & $636 \mathrm{~K}$ & $418 \mathrm{~K}$ & $2,311,690$ & $\$ 4,544.02$ & 3 & $4-$ \\
\hline UC Berkeley & $2,773,113^{37}$ & 462,620 & $155 \mathrm{~K}$ & $124 \mathrm{~K}$ & 741,620 & $\$ 3,739.26$ & 4 & $2-$ \\
\hline Oxford (UK) & $\begin{array}{l}1,774,190^{38}\left({ }^{*} \text { converted }\right. \\
\text { to dollars })\end{array}$ & $3,564,347$ & $478 \mathrm{~K}$ & $391 \mathrm{~K}$ & $4,433,347$ & $\$ 400.19$ & 5 & $4+$ \\
\hline Caltech & $2,937,830^{39}$ & 378,819 & $60.7 \mathrm{~K}$ & $31.9 \mathrm{~K}$ & 471,419 & $\$ 6,231.88$ & 6 & $3-$ \\
\hline $\begin{array}{l}\text { University of } \\
\text { Cambridge (UK) }\end{array}$ & $\begin{array}{l}2,294,890^{40}(* \text { converted } \\
\text { to dollars) }\end{array}$ & $2,110,201$ & $431 \mathrm{~K}$ & $396 \mathrm{~K}$ & $2,937,201$ & $\$ 781.31$ & 7 & $4+$ \\
\hline Columbia & $4,384,914^{41}$ & 372,524 & $291 \mathrm{~K}$ & $159 \mathrm{~K}$ & 822,524 & $\$ 5,938.53$ & 8 & 0 \\
\hline Princeton & $1,615,975^{42}$ & 566,493 & $329 \mathrm{~K}$ & $203 \mathrm{~K}$ & $1,098,493$ & $\$ 1,471.08$ & 9 & $5+$ \\
\hline $\begin{array}{l}\text { University of } \\
\text { Washington }\end{array}$ & $5,666,000^{43}$ & 337,483 & $155 \mathrm{~K}$ & $91.9 \mathrm{~K}$ & 584,383 & $\$ 9,695.69$ & 10 & 0 \\
\hline $\begin{array}{l}* \text { social media data } \\
\text { retrieved on } \\
10 / 29 / 2018\end{array}$ & & & & & & & & $\begin{array}{l}26+/-(52 \% \\
\text { miscorelation) }\end{array}$ \\
\hline
\end{tabular}

Please refer to the References section for social media citation information

\section{Results}

Data reported for the top 10 global universities revealed Princeton having the greatest miscorrelation of 5+. Columbia and the University of Washington were the only universities with no miscorrelations, leaving $80 \%$ of the top 10 global universities as having a miscorrelation of $1+/-$ or more. The data reported a total miscorrelation factor of $26+/-(52 \%$ miscorrelation $)$ making the global assessment the least correlated of the three assessments.

33 “The Best Universities in the World," U.S. News \& World Report, https://www.usnews.com/education/bestglobal-universities/rankings, (October 29, 2018).

${ }^{34}$ PricewaterhouseCoopers LLP, FINANCIAL REPORT FISCAL YEAR 2017 (Harvard): 15.

35 PricewaterhouseCoopers LLP, MIT REPORT OF THE TREASURER 2017: 13.

${ }^{36}$ PricewaterhouseCoopers LLP, Stanford University Annual Financial Report August 31, 2017 and $2016: 28$.

${ }^{37}$ UNIVERSITY OF CALIFORNIA, BERKELEY Annual Financial Report 2016-17: 4

${ }^{38}$ KPMG LLP, comp. Financial Statements 2016/17: 33

${ }^{39}$ PricewaterhouseCoopers LLP, comp. California Institute of Technology Financial Statements For the Years Ended September 30, 2017 and 2016: 5

${ }^{40}$ PricewaterhouseCoopers LLP, comp. Reports and Financial Statements for the Year Ended 31 July 2017: 61

${ }^{41}$ PricewaterhouseCoopers LLP, The Trustees of Columbia University in the City of New York Consolidated Financial Statements June 30, 2018 and 2017: 4.

${ }^{42}$ PricewaterhouseCoopers LLP, Report of the Treasurer 2016-2017 (Princeton): 10.

${ }^{43}$ PricewaterhouseCoopers LLP, comp. Financial Report 2017 (University of Washington): 15.

(C) 2018 Patrick R. Goncalves M.S.

This open access article is licensed under a Creative Commons Attribution: Non-Commercial license.

DOI: JMCHE/v1i102 


\section{Conclusion}

In comparing the three assessments, Massachusetts, U.S. national and global, the data reported the greatest total miscorrelation for the global assessment with a total miscorrelation factor of 26 +/-. The Massachusetts assessment reported a total miscorrelation factor of 20 +/-. The U.S. national assessment reported the least total miscorrelation factor of $17+/-$. Even though the Massachusetts assessment didn't report the least total miscorrelation factor, the assessment did report the highest number of exact correlations (cost per follower ranking in correlation with U.S. News ranking i.e. 0 miscorrelation factor) of $6(60 \%$ of the top 10 national universities in MA). While the U.S. national assessment reported the least total miscorrelation factor, the assessment also reported zero exact correlations ( $0 \%$ of the top 10 U.S. national universities). The global assessment reported two university correlations $(20 \%$ of the top 10 global universities).

Based on the data, we can determine that overall, social media efficiency and U.S. News rankings proved to have at least a $60 \%$ correlation, in regards to miscorrelation factor and an exact correlation of $26.6 \%$. Within the three assessments, the greatest correlations consistently occurred at rankings \#1 and \#2 and ranking number \#10, with the greatest degree of miscorrelations occurring in various spots between rankings \#1 through \#9. As a result, there isn't enough convincing data to prove a consistent correlating pattern outside the close correlations between the top two rankings and the tenth ranking. This recurring result can be explained by the long tail theory. In particular with regard to reputation-based indicator weight scores; consistent top $20 \%$ rankings could simply be the result of institutional brand recognition, whereby there is more competition and variability occurring outside the top $20 \%$ of the top 10 .

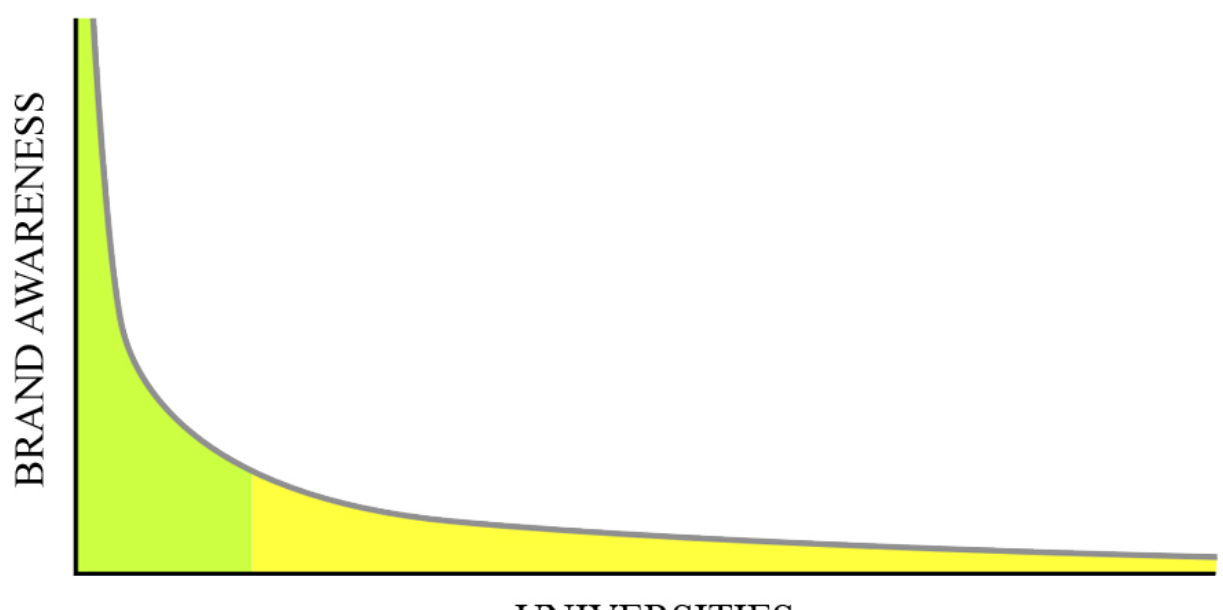

UNIVERSITIES

Figure 2. Long Tail Theory Distribution of University Brand Awareness

(C) 2018 Patrick R. Goncalves M.S.

This open access article is licensed under a Creative Commons Attribution: Non-Commercial license. DOI: JMCHE/v1i102 


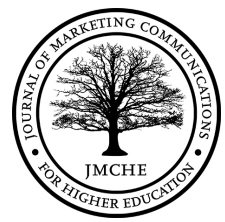

In regards to social media efficiency, all three assessments confirmed that older, more established universities displayed a greater propensity for social media efficiency. Worth noting, the top four global universities with the most efficient cost per follower, are among the oldest institutions in the world; Oxford (\$400.19 cost per follower) established c. $1096^{44}$, Harvard ( $\$ 691.90$ cost per follower) established in $1636^{45}$ (oldest university in the U.S.), the University of Cambridge (\$781.31 cost per follower) established in $1209^{46}$ and Princeton $(\$ 1471.08$ cost per follower) established in $1746^{47}$.

The oldest university in the world, the University of Al Quaraouyine, was established in $859^{48}$; according to Aaker's brand equity model, the "heritage factor" that's attributed to the University of Al Quaraouyine should be enough to catapult the university's brand awareness. In contrast, the University of Al Quaraouyine is not ranked in U.S. News \& World Report ${ }^{49}$ or even Time Higher $\mathrm{Ed}^{50}$; in fact, Morocco World News reported that the university wasn't even among the 500 world's best ${ }^{51}$. According to the University of Al Quaraouyine's website, the university doesn't utilize any form of social media ${ }^{52}$. All the universities that were assessed in this study have varying degrees of actual marketing expense covering varying percentages of total operating expense. As a result, we can deduce that universities with a lower cost per follower are most likely allocating larger budget percentages toward traditional, as well as, new media marketing and communications strategies and services.

\footnotetext{
44 "Introduction and History," University of Oxford https://www.ox.ac.uk/about/organization/history?wssl=1, (November 01,2018).

45 “'About Harvard,’Harvard University, https:/www.harvard.edu/about-harvard, (November 01, 2018).

46 "Early Records,"” University of Cambridge, https://www.cam.ac.uk/about-the-university/history/early-records, (November 01, 2018).

47 “About Princeton University," Princeton University, https://profile.princeton.edu/about, (November 01, 2018).

${ }^{48}$ Davies, Julie, and David Buisson, "Happy Anniversary? What's the Point of a Business School Anniversary? 'Remembering' and Re-energising for the next One According to Julie Davies and David Buisson," EFMD Global Focus, 3rd ed. Vol. 11. (2017): 1-4.

49 The Best Universities in the World," U.S. News \& World Report, https:/www.usnews.com/education/best-globaluniversities/rankings, (October 29, 2018).

50 "World University Rankings," Times Higher Education (THE), https://www.timeshighereducation.com/worlduniversity-rankings, (October 29, 2018).

${ }^{51}$ Igouane Youssef, "No Moroccan University among 500 World's Best Universities," https://www.moroccoworldnews.com/2016/08/194244/no-moroccan-university-among-500-worlds-bestuniversities/, (December 04, 2018).

52 “University of Al Quaraouyine website,” http://uaq.ma/index.php/forward-president-of-al-quaraouyine-university, (November 4, 2018).
}

(C) 2018 Patrick R. Goncalves M.S.

This open access article is licensed under a Creative Commons Attribution: Non-Commercial license.

DOI: JMCHE/vli102 


\title{
INDEX A: Definitions of Ranking Criteria for U.S. News \& Report National Universities Rankings (2019)
}

\begin{abstract}
Average alumni giving rate: The average percentage of undergraduate alumni of record who donated money to the college or university. Alumni of record are former full- or part-time students who received an undergraduate degree and for whom the college or university has a current address. Graduates who earned only a graduate degree are excluded.
\end{abstract}

Undergraduate alumni donors are alumni with undergraduate degrees from an institution who made one or more gifts for either current operations or capital expenses during the specified academic year.

The alumni giving rate is calculated by dividing the number of alumni donors during a given academic year by the number of alumni of record for that same year. The two most recent years of alumni giving rates that are available are averaged (added together and divided by two) and used in the rankings. For the 2019 edition, the two separately calculated alumni giving rates that were averaged were for giving in the 2015-2016 and 2016-2017 academic years.

The percentage of alumni giving serves as a proxy for how satisfied students are with the school. A higher average alumni giving rate scores better than a lower rate in the ranking model.

Average first-year student retention rate: The percentage of first-year students who returned to the same college or university the following fall. The average first-year student retention rate indicates the average proportion of the first-year classes entering from fall 2013 through fall 2016 who returned the following fall.

If a school submits fewer than four years of first-year retention rate data, then the average is based on the number of years that a school submits to U.S. News. A higher average first-year retention rate scores better than a lower average retention rate in the ranking model.

Average graduation rate: The percentage of entering first-year students who graduated within a six-year period or less, averaged over the classes entering from fall 2008 through fall 2011. This excludes students who transferred into the school after their first year and then graduated.

If a school submits fewer than four years of graduation rate data, then the average is based on the number of years the school submits. A higher average graduation rate scores better than a lower graduation rate in the ranking.

Class size: For the third year in row, class size has one component. The one class size index score takes fuller advantage of the full range of fall 2017 class size data that schools report to U.S. News.

Schools receive the most credit in this index for their proportions of undergraduate classes with fewer than 20 students. Classes with 20 to 29 students score second highest, 30 to 39 students third highest and 40 to 49 students fourth highest. Classes that are 50 or more students receive no credit.

Expenditures per student: Financial resources are measured by the average spending per full-time-equivalent student on instruction, research, public service, academic support, student services and institutional support during the 2016 and 2017 fiscal years. If a school submits fewer than two years of data, then one year is used.

The number of full-time-equivalent undergraduate and graduate students is equal to the number of full-time students plus onethird the number of part-time students.

U.S. News first scales the public service and research values by the percentage of full-time-equivalent undergraduate students attending the school. Next, U.S. News adds total instruction, academic support, student services and institutional support, and then divides by the number of full-time-equivalent students. After calculating this value, U.S. News applies a logarithmic transformation to it prior to standardizing.

Financial resources enable schools to provide students with a high-quality college experience. Consequently, higher average expenditures per student score better than lower expenditures in the ranking model. However, the use of the logarithmic

(C) 2018 Patrick R. Goncalves M.S.

This open access article is licensed under a Creative Commons Attribution: Non-Commercial license.

DOI: JMCHE/v1i102 
transformation means schools that have expenditures per student that are far higher than most other schools' values see diminishing benefits in the ranking calculations.

Faculty compensation: The average faculty pay and benefits are adjusted for regional differences in cost of living. This includes full-time assistant, associate and full professors. The values are taken for the 2016-2017 and 2017-2018 academic years and then averaged.

If a school submits fewer than two years of faculty salary data, then U.S. News uses only one year. The regional differences in cost of living are taken from indexes from consulting firm Runzheimer International.

Higher average faculty salaries after adjusting for regional cost of living score better than lower average faculty salaries in the ranking model.

Faculty with a doctoral or terminal degree: The percentage of full-time faculty members with a doctorate or the highest degree possible in their field or specialty during the 2017-2018 academic year. Schools with a larger proportion of full-time faculty with the terminal degree in their field score better than schools with a lower proportion.

Graduation rate performance: A comparison between the actual six-year graduation rate for students entering in fall 2011 and the predicted graduation rate for the proportion who graduated six years later in 2017 . The predicted graduation rate is based upon characteristics of the entering class, as well as characteristics of the institution.

If the actual graduation rate is higher than the predicted rate, the college is enhancing achievement or is overperforming. If its actual graduation rate is lower than the predicted rate, then it's underperforming. U.S. News divided the actual rate by the predicted rate. The higher the ratio, the better the score.

This indicator of added value shows the effect of the college's programs and policies on the six-year graduation rate of students after controlling for spending per student, the proportion of undergraduates receiving Pell Grants, standardized test scores and high school class standing. For the second consecutive year, the proportion of science, technology, engineering and math, or STEM, degrees out of the total degrees granted was a variable used to calculate the predicted graduation rate for each school in the National Universities ranking category only.

To determine whether an awarded degree was considered STEM, U.S. News used the U.S. Department of Homeland Security's STEM Designated Degree Program list. The list includes a diverse array of degrees in general STEM areas, such as biology and engineering, as well as specific STEM degree tracks in nontraditional STEM fields, such as business statistics and digital communication and media. Adding this factor to spending and student profile data made the analysis more accurate; that is, the predicted graduation rates more closely mirror actual graduation rates.

Graduation rate performance has been used in the National Universities and National Liberal Arts Colleges ranking categories since the 1997 edition of Best Colleges, and in the Regional Universities and Regional Colleges ranking categories starting with the 2014 edition.

High school class standing: The proportion of students enrolled for the academic year beginning in fall 2017 who graduated in the top 10 percent (for National Universities and National Liberal Arts Colleges) or top 25 percent (Regional Universities and Regional Colleges) of their high school class.

A higher proportion of students from either the top 10 percent or top 25 percent of their high school class scores better than lower proportions in the ranking model. Colleges reporting high school class standing based on less than 20 percent of their entering classes had their scores discounted before being used in the rankings.

Ranked schools on average reported high school class standing on 59 percent of the entering class.

High school counselor rating score: Opinions of high school guidance counselors are only factored into the rankings of National Universities and National Liberal Arts Colleges. These ratings by public and private independent school counselors are used as an indicator of academic reputation in these two categories, along with separate ratings from college admissions deans, provosts and presidents.

(C) 2018 Patrick R. Goncalves M.S.

This open access article is licensed under a Creative Commons Attribution: Non-Commercial license.

DOI: JMCHE/v1i102 
Vol 1 Issue 1 (2018)

Scores for each school are totaled and divided by the number of counselors who rated that school.

The three most recent years of survey results - spring 2016, 2017 and 2018 - were averaged to compute the used in the rankings. This increases the number of ratings each school received and more fully represents the views of guidance counselors, as well as reduces the year-to-year volatility in the average counselor score.

A higher average high school counselor reputation score does better than a lower score in the ranking model. The Regional Colleges and Regional Universities rankings do not have a high school counselor ratings component.

Peer assessment: A measure of how a school is regarded by administrators at peer institutions. A school's peer assessment score is determined by surveying presidents, provosts and deans of admissions, or officials in equivalent positions, at institutions in the school's ranking category.

Each individual is asked to rate peer schools' undergraduate academic programs on a scale from 1 (marginal) to 5 (distinguished). Those individuals who do not know enough about a school to evaluate it fairly are asked to mark "don't know."

A school's score is the average score of all the respondents who rated it. Responses of "don't know" count neither for nor against a school.

The two most recent years of peer assessment survey results - spring 2017 and 2018 - were averaged to compute the academic reputation peer assessment score used in the rankings. This increases the number of ratings each school received and more fully represents the views of high-level academics, as well as reduces the year-to-year volatility in the average peer assessment score.

The response rate was 35.5 percent for the spring 2018 survey, compared with 40.4 percent for the spring 2017 surveys and 39 percent for the spring 2016 surveys.

A higher average peer assessment score does better than a lower peer assessment score in the ranking model. The academic peer assessment rating is used in the National Universities, National Liberal Arts Colleges, Regional Universities and Regional Colleges rankings.

Pell Grant graduation rates: This new social mobility ranking indicator measures the success of Pell Grant students on an absolute basis. To calculate this indicator, we use a school's six-year graduation rate among new fall 2011 entrants receiving Pell Grants. This assesses each school's performance of graduating students from low-income backgrounds. A higher Pell Grant graduation rate scores better than a lower one. Because achieving results from a broader base is more challenging, schools whose fall 2011 cohorts were comprised of less than 50 percent Pell students, we multiplied their Pell graduation rates by the proportion that is Pell. For all remaining schools that demonstrated significant economic diversity by being comprised of at least 50 percent Pell students, we multiplied their Pell graduation rates by 0.5 .

Pell Grant graduation rates compared with non-Pell students: This new social mobility ranking indicator assesses success at achieving equitable outcomes for students from underserved backgrounds. It divides each school's six-year graduation rate among fall 2011 new entrant Pell recipients to this rate among non-Pell recipients, with higher ratios scoring better than lower ratios. The significant minority of schools whose Pell graduation rates are equal to or greater than non-Pell graduation rates receive the best possible score of 1 , pending adjustment for the proportion of the entering class that received Pell Grants. Schools whose cohorts were at least 50 percent Pell students have their scores augmented by 0.5 ; schools below 50 percent Pell students had their scores augmented by the proportion that received Pell Grants.

Proportion of full-time faculty: The proportion of the 2017-2018 faculty that is full time. We divide the count of full-time faculty members by the count of full-time-equivalent faculty members (full-time faculty members plus one-third the count of part-time faculty members).

U.S. News does not include faculty in preclinical and clinical medicine; administrative officers with titles such as dean of students, librarian, registrar or coach, even though they may devote part of their time to classroom instruction and may have

(C) 2018 Patrick R. Goncalves M.S.

This open access article is licensed under a Creative Commons Attribution: Non-Commercial license.

DOI: JMCHE/v1i102 
faculty status; undergraduate or graduate students who are teaching assistants or teaching fellows; faculty members on leave without pay; or replacement faculty for those faculty members on sabbatical leave.

To calculate this percentage, the total full-time faculty is divided by the full-time-equivalent faculty. A higher proportion of faculty members who are full time scores better than a lower proportion in the ranking model.

SAT/ACT scores: Average test scores on both the SAT math and evidence-based reading and writing and math portions, and the composite ACT of all enrolled first-time, first-year students entering in fall 2017 are combined for the ranking model.

Before being used as a ranking indicator, the reported scores from both SAT tests and the ACT composite test are each converted to their national percentile distributions. Because U.S. News uses percentile distributions, any differences in reported scores between old and new SAT exams should not directly manifest in the rankings.

To most accurately represent the entire entering class, we use a calculation based on the percentage of the fall entering class that submitted each test. For example, if twice as many applicants to a school submitted ACT scores versus SAT scores, then the ACT scores would have twice as much effect on that school's ranking.

Schools were instructed to report scores for all exams they had on record, including in cases when an exam was not used in the admissions decision. Schools that excluded groups of students in their reporting - such as student athletes and international students - had their test scores discounted in the calculations. Separately, schools that reported a total count of SAT and ACT submissions that was less than 75 percent of their fall 2017 entering classes also had their test scores discounted in the ranking calculations.

The SAT scores used in the 2019 edition of the Best Colleges rankings and published on usnews.com for each school are for the fall 2017 entering class and are for the new SAT test. A higher average entering class test score on the SAT math and evidence-based reading and writing portions and the composite ACT does better than a lower average SAT and ACT test score in the ranking model.

Student-faculty ratio: The ratio of full-time-equivalent students to full-time-equivalent faculty members during fall 2017.

This excludes faculty and students of law, medical, business and other stand-alone graduate or professional programs in which faculty members teach virtually only graduate-level students. Faculty numbers also exclude graduate or undergraduate students who are teaching assistants.

Each school's student-faculty ratio is compared with the largest ratio reported in its ranking category. Consequently, a lower student-faculty ratio (fewer students per each faculty member) scores better than a higher ratio in the ranking model. 
Vol 1 Issue 1 (2018)

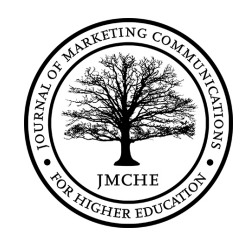

\title{
INDEX B: Definitions of Ranking Criteria for U.S. News \& Report Global Universities Rankings (2019)
}

\author{
Reputation Indicators: Results from Clarivate Analytics' Academic Reputation Survey were used to create the \\ two reputation indicators used in U.S. News' ranking analysis. \\ The survey, which aimed to create a comprehensive snapshot of academics' opinions about world universities, asked \\ respondents to give their views of programs in the disciplines with which they were familiar. This method allowed \\ respondents to rate universities at the field and department level, rather than at the institution level, creating a more specific \\ and accurate measurement of a university's reputation as a whole.
}

To appropriately represent all regions, Clarivate Analytics took steps to overcome language bias, differing response rates and the geographic distribution of researchers. These steps included:

- Sending an invitation-only survey to academics selected from Clarivate Analytics' databases of published research, based on the estimated geographic proportions of academics and researchers around the world.

- $\quad$ Providing accessibility in seven languages.

- Rebalancing the survey's final results based on the geographic distribution of researchers to overcome differing response rates.

- Excluding respondents' nominations of their own institution or alma mater.

Respondents also self-declared their job role:

- 67 percent academic staff.

- 16 percent research staff.

- 7 percent senior institutional leaders.

- 3 percent graduate/postgraduate students.

- 7 percent other jobs and roles.

The total number of unique respondents was more than 28,000 . The survey results were used in two separate ranking indicators, as follows.

Global research reputation (12.5 percent): This indicator reflects the aggregation of the most recent five years of results of the Academic Reputation Survey for the best universities globally for research. (Reputation Indicator)

Regional research reputation (12.5 percent): This indicator reflects the aggregation of the most recent five years of results of the Academic Reputation Survey for the best universities for research in the region; regions were determined based on the United Nations definition.

This regional indicator had the effect of significantly increasing the international diversity of the rankings, since it focused on measuring academics' opinions of other universities within their region. The U.S. News rankings are the only global rankings to use this indicator, and the 2019 edition marks the fifth year of its inclusion. (Reputation Indicator)

Bibliometric Indicators: The bibliometric indicators used in the U.S. News ranking analysis are based on data from Clarivate Analytics' Web of Science for the five-year period from 2012-2016. The Web of Science is a web-based research platform that covers more than 18,000 of the most influential and authoritative scholarly journals worldwide in the sciences, social sciences, and arts and humanities.

Publications (10 percent): This is a measure of the overall research productivity of a university, based on the total number of scholarly papers - reviews, articles and notes - that contain affiliations to a university and are published in high-quality, impactful journals. This indicator is closely linked to the university's size. It is also influenced by the university's discipline focus, since some disciplines, particularly medicine, publish more than others. (Bibliometric Indicator)

(C) 2018 Patrick R. Goncalves M.S.

This open access article is licensed under a Creative Commons Attribution: Non-Commercial license.

DOI: JMCHE/v1i102 
Books (2.5 percent): Books are an important medium of publication for scholarly research, particularly in the social sciences, arts and humanities. The use of this ranking indicator provides a useful supplement to the data on articles and better represents universities that have a focus on social sciences and arts and humanities. (Bibliometric Indicator)

Conferences (2.5 percent): Academic conferences are an important venue for scholarly communication, particularly in disciplines tied to engineering and computer science. The formal publication of conference proceedings can represent genuine research breakthroughs in certain fields that may not have been documented or published elsewhere. (Bibliometric Indicator)

Normalized citation impact (10 percent): The total number of citations per paper represents the overall impact of the research of the university and is independent of the university's size or age; the value is normalized to overcome differences in research area, the paper's publication year and publication type.

$\mathrm{NCI}$ is considered one of the core measures of research performance and is used by various research evaluation bodies globally. The subject fields used in the analysis came from Clarivate Analytics InCites, which helps institutions evaluate research output, performance and trends; understand the scope of an organization's scholarly contributions; and articulate outcomes to inform research priorities. InCites uses the content and citation indicators found in the Web of Science. (Bibliometric Indicator)

Total citations ( 7.5 percent): This indicator measures how influential the university has been on the global research community. It is determined by multiplying the publications ranking factor by the normalized citation impact factor. Total citations have been normalized to overcome differences in research area, publication year of the paper and publication type. (Bibliometric Indicator)

Number of publications that are among the 10 percent most cited (12.5 percent): This indicator reflects the number of papers that have been assigned as being in the top 10 percent of the most highly cited papers in the world for their respective fields. Each paper is given a percentile score that represents where it falls, in terms of citation rank, compared with similar papers - those with the same publication year, subject and document type.

Since the number of highly cited papers is dependent on the university's size, the indicator can be considered a robust indication of how much excellent research the university produces. (Bibliometric Indicator)

Percentage of total publications that are among the 10 percent most cited (10 percent): This indicator is the percentage of a university's total papers that are in the top 10 percent of the most highly cited papers in the world - per field and publication year. It is a measure of the amount of excellent research the university produces and is independent of the university's size. (Bibliometric Indicator)

International collaboration (5 percent): This indicator is the proportion of the institution's total papers that contain international co-authors divided by the proportion of internationally co-authored papers for the country that the university is in. It shows how international the research papers are compared with the country in which the institution is based. International collaborative papers are considered an indicator of quality, since only the best research will be able to attract international collaborators. (Bibliometric Indicator)

Percentage of total publications with international collaboration (5 percent): This indicator is the proportion of the institution's total papers that contain international co-authors and is another measure of quality. (Bibliometric Indicator) Number of highly cited papers that are among the top 1 percent most cited in their respective field (5 percent): This highly cited papers indicator shows the volume of papers that are classified as highly cited in the Clarivate Analytics' service known as Essential Science Indicators. Highly cited papers in ESI are the top 1 percent in each of the 22 subject areas represented in the Web of Science, per year. They are based on the most recent 10 years of publications. (Scientific Excellence Indicators)

Percentage of total publications that are among the top 1 percent most highly cited papers (5 percent): This percent of highly cited papers shows the number of highly cited papers for a university divided by the total number of documents it produces, represented as a percentage. It is a measure of excellence and can show what percentage of an institution's output is among the most impactful papers in the world. This is a size-independent measure. (Scientific Excellence Indicators)

(C) 2018 Patrick R. Goncalves M.S.

This open access article is licensed under a Creative Commons Attribution: Non-Commercial license.

DOI: JMCHE/vli102 
Vol 1 Issue 1 (2018)

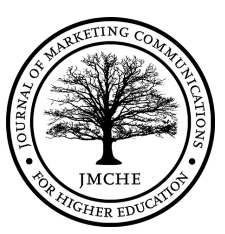

\section{References}

Aaker, David A. Building Strong Brands. New York: Free Press, 1996.

"About Harvard." Harvard University. Accessed November 01, 2018. https://www.harvard.edu/about-harvard.

"About Princeton University | A Princeton Profile." Princeton University. Accessed November 01, 2018. https://profile.princeton.edu/about.

Account, Boston CollegeVerified. "Boston College (@BostonCollege)." Twitter. October 24, 2018. Accessed October 24, 2018.

https://witter.com/BostonCollege?ref_src=twsrc ${ }^{\wedge}$ google|twcamp ${ }^{\wedge} \operatorname{serp} \mid$ twgr $^{\wedge}$ author.

Account, Boston UniversityVerified. "Boston University (@BU_Tweets)." Twitter. October 24, 2018. Accessed October 24, 2018.

https://twitter.com/BU_Tweets?ref_src $=$ twsrc $^{\wedge}$ google|twcamp ${ }^{\wedge} \operatorname{serp} \mid$ twgr $^{\wedge}$ author. $^{-}$

Account, CaltechVerified. "Caltech (@Caltech)." Twitter. October 29, 2018. Accessed October 29, 2018. https://twitter.com/Caltech?ref_src=twsrc ${ }^{\wedge}$ google|twcamp^serp|twgr^author.

Account, Cambridge UniversityVerified. "Cambridge University (@Cambridge_Uni)." Twitter. October 29, 2018. Accessed October 29, 2018.

https://twitter.com/Cambridge_Uni?ref_src=twsrc ${ }^{\wedge}$ google $\mid$ twcamp ${ }^{\wedge} \operatorname{serp} \mid \operatorname{twgr}^{\wedge}$ author.

Account, Duke UniversityVerified. "Duke University (@DukeU)." Twitter. October 29, 2018. Accessed October 29, 2018. https://twitter.com/DukeU?ref_src $=$ twsrc $^{\wedge}$ google|twcamp ${ }^{\wedge} \operatorname{serp} \mid$ twgr $^{\wedge}$ author.

Account, Harvard UniversityVerified. "Harvard University (@Harvard)." Twitter. October 24, 2018. Accessed October 24, 2018.

https://twitter.com/Harvard?ref_src=twsrc ${ }^{\wedge}$ google|twcamp^serp|twgr^${ }^{\wedge}$ author.

Account, Johns Hopkins U.Verified. "Johns Hopkins U. (@JohnsHopkins)." Twitter. October 29, 2018. Accessed October 29, 2018.

https://twitter.com/JohnsHopkins?ref_src=twsrc ${ }^{\wedge}$ google $\mid$ twcamp ${ }^{\wedge} \operatorname{serp} \mid \operatorname{twgr}{ }^{\wedge}$ author.

Account, Northeastern U.Verified. "Northeastern U. (@Northeastern)." Twitter. October 24, 2018. Accessed October 24, 2018.

https://twitter.com/Northeastern?ref_src $=$ twsrc $^{\wedge}$ google|twcamp ${ }^{\wedge} \operatorname{serp} \mid \operatorname{twgr}^{\wedge}$ author.

(C) 2018 Patrick R. Goncalves M.S.

This open access article is licensed under a Creative Commons Attribution: Non-Commercial license.

DOI: JMCHE/v1i102 
Account, Oxford UniversityVerified. "Oxford University (@UniofOxford)." Twitter. October 29, 2018. Accessed October 29, 2018.

https://twitter.com/UniofOxford?ref_src=twsrc ${ }^{\wedge}$ google|twcamp^serp|twgr^author.

Account, PennVerified. "Penn (@Penn)." Twitter. October 29, 2018. Accessed October 29, 2018. https://twitter.com/Penn?ref_src=twsrc ${ }^{\wedge}$ google|twcamp^serp|twgr^author.

Account, Princeton UniversityVerified. "Princeton University (@Princeton)." Twitter. October 29, 2018. Accessed October 29, 2018.

https://twitter.com/Princeton?ref_src=twsrc ${ }^{\wedge}$ google|twcamp^serp|twgr^author.

Account, Stanford UniversityVerified. "Stanford University (@Stanford)." Twitter. October 29, 2018. Accessed October 29, 2018.

https://twitter.com/Stanford?ref_src=twsrc ${ }^{\wedge}$ google|twcamp^serp|twgr^author.

Account, Tufts UniversityVerified. "Tufts University (@TuftsUniversity)." Twitter. October 24, 2018. Accessed October 24, 2018.

https://twitter.com/TuftsUniversity?ref_src=twsrc ${ }^{\wedge}$ google|twcamp ${ }^{\wedge}$ serp|twgr^author.

Account, UC BerkeleyVerified. "UC Berkeley (@UCBerkeley)." Twitter. October 29, 2018. Accessed October 29, 2018.

https://twitter.com/UCBerkeley?ref_src=twsrc ${ }^{\wedge}$ google|twcamp^serp|twgr^author.

Account, UChicagoVerified. "UChicago (@UChicago)." Twitter. October 29, 2018. Accessed October 29, 2018.

https://twitter.com/UChicago?ref_src=twsrc ${ }^{\wedge}$ google|twcamp^serp|twgr^author.

Account, UMassVerified. "UMass (@UMass)." Twitter. October 24, 2018. Accessed October 24, 2018. https://twitter.com/UMass.

Account, University Of WashingtonVerified. "University of Washington (@UW)." Twitter. October 29, 2018. Accessed October 28, 2018. https://twitter.com/UW?ref_src=twsrc ${ }^{\wedge}$ google|twcamp^serp|twgr^author.

Account, WPIVerified. "WPI (@WPI)." Twitter. October 24, 2018. Accessed October 24, 2018. https://twitter.com/WPI?ref_src=twsrc ${ }^{\wedge}$ google|twcamp ${ }^{\wedge}$ serp|twgr^author.

Account, Yale UniversityVerified. "Yale University (@Yale)." Twitter. October 29, 2018. Accessed October 29, 2018. https://twitter.com/Yale?ref_src=twsrc ${ }^{\wedge}$ google|twcamp^serp|twgr^author.

(C) 2018 Patrick R. Goncalves M.S.

This open access article is licensed under a Creative Commons Attribution: Non-Commercial license.

DOI: JMCHE/v1i102 
"Boston College." Boston College Facebook. Accessed October 24, 2018. https://www.facebook.com/BostonCollege/.

"Boston College (@bostoncollege)・Instagram Photos and Videos." Instagram. Accessed October 24, 2018. https://www.instagram.com/bostoncollege/?hl=en.

"Boston University." Boston University Facebook. Accessed October 24, 2018. https://www.facebook.com/BostonUniversity/.

"Boston University (@bostonu) • Instagram Photos and Videos." Instagram. Accessed October 24, 2018. https://www.instagram.com/bostonu/?hl=en.

"Brandeis University." Brandeis University Facebook. Accessed October 24, 2018. https://www.facebook.com/brandeisuniversity/.

"Brandeis University (@brandeisuniversity) • Instagram Photos and Videos." Instagram. Accessed October 24, 2018. https://www.instagram.com/brandeisuniversity/?hl=en.

"Caltech." Caltech Facebook. Accessed October 29, 2018. https://www.facebook.com/californiainstituteoftechnology/.

"Caltech (@caltechedu)• Instagram Photos and Videos." Instagram. Accessed November 29, 2018. https://www.instagram.com/caltechedu/?hl=en.

"Clark University." Clark University Facebook. Accessed October 24, 2018. https://www.facebook.com/ClarkUniversityWorcester/.

"Clark University (@clarkuniversity)• Instagram Photos and Videos." Instagram. Accessed October 24, 2018. https://www.instagram.com/clarkuniversity/?hl=en.

"Columbia University (@Columbia)." Twitter. October 29, 2018. Accessed October 29, 2018. https://witter.com/Columbia?ref_src $=$ twsrc $^{\wedge}$ google|twcamp ${ }^{\wedge} \operatorname{serp} \mid \operatorname{twgr}^{\wedge}$ author.

"Columbia University (@columbia)・Instagram Photos and Videos." Instagram. Accessed October 29, 2018. https://www.instagram.com/columbia/?hl=en.

"Columbia University in the City of New York." Columbia University in the City of New York Facebook. Accessed October 29, 2018. https://www.facebook.com/columbia/.

(C) 2018 Patrick R. Goncalves M.S.

This open access article is licensed under a Creative Commons Attribution: Non-Commercial license. DOI: JMCHE/v1i102 
Vol 1 Issue 1 (2018)

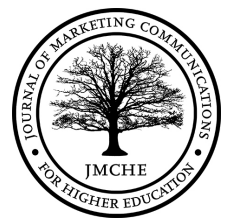

Compass, U.S. News College, and Read The Best Colleges Methodology. "The 10 Best Universities in America." U.S. News \& World Report. Accessed October 24, 2018. https://www.usnews.com/best-colleges/rankings/national-universities.

Davies, Julie, and David Buisson. Happy Anniversary? What's the Point of a Business School Anniversary? 'Re-membering' and Re-energising for the next One According to Julie Davies and David Buisson. Publication. 3rd ed. Vol. 11. EFMD Global Focus. 1-4.

"Duke University." Duke University Facebook. Accessed October 29, 2018. https://www.facebook.com/DukeUniv/.

"Duke University (@dukeuniversity) • Instagram Photos and Videos." Instagram. Accessed October 29, 2018. https://www.instagram.com/dukeuniversity/?hl=en.

"Early Records." University of Cambridge. January 28, 2013. Accessed November 01, 2018. https://www.cam.ac.uk/about-the-university/history/early-records.

Grant Thornton LLP, comp. 2017 ANNUAL FINANCIAL REPORT. Report. Treasury Department, The University of Massachusetts. Boston, MA: UMASS, 2017. 1-57.

Grant Thornton LLP, comp. Consolidated Financial Statements and Report of Independent Certified Public Accountants: Clark University May 31,2017 and 2016. Report. Treasury Department, Clark University. Worcester, MA: Clark University, 2017. 1-37.

"Harvard University." Harvard University Facebook. Accessed October 24, 2018. https://www.facebook.com/Harvard/.

"Harvard University (@harvard)•Instagram Photos and Videos." Instagram. Accessed October 24, 2018. https://www.instagram.com/harvard/?hl=en.

Igrouane, Youssef. "No Moroccan University among 500 World's Best Universities." Morocco World News. August 22, 2016. Accessed December 04, 2018. https://www.moroccoworldnews.com/2016/08/194244/no-moroccan-university-among-500worlds-best- universities/.

"Introduction and History." University of Oxford. Accessed November 1, 2018. https://www.ox.ac.uk/about/organisation/history?wssl=1.

(C) 2018 Patrick R. Goncalves M.S.

This open access article is licensed under a Creative Commons Attribution: Non-Commercial license. DOI: JMCHE/v1i102 
"Johns Hopkins University." Johns Hopkins University Facebook. Accessed October 29, 2018. https://www.facebook.com/johnshopkinsuniversity/.

"Johns Hopkins University (@johnshopkinsu)• Instagram Photos and Videos." Instagram. Accessed October 29, 2018. https://www.instagram.com/johnshopkinsu/?hl=en.

KPMG LLP. Brandeis University: Financial Statments. Report. Treasury Department, Brandeis University. Waltham, MA: Brandeis University, 2017. 1-22.

KPMG LLP, comp. Boston University Financial Statements June 30, 2017 and 2016. Report. Treasury Department, Boston University. Boston, MA: Boston University, 2017. 1-30.

KPMG LLP, comp. THE JOHNS HOPKINS UNIVERSITY Consolidated Financial Statements and Independent Auditors' Reports Required by Title 2 U.S. Code of Federal Regulations Part 200, Uniform Administrative Requirements, Cost Principles, and Audit Requirements for Federal Awards, and Related Information Year Ended June 30, 2017 (With Independent Auditors' Report Thereon). Report. Treasury Department, Johns Hopkins University. Baltimore, MD: Johns Hopkins University, 2017. 1-89.

KPMG LLP, comp. Financial Statements 2016/17. Report. Treasury Department, University of Oxford. Oxford, England: University of Oxford, 2017. 1-84.

KPMG LLP, comp. Duke University Financial Statements 2017/2018. Report. Treasury Department, Duke University. Durham, NC: Duke University, 2018. 1-52.

"Massachusetts Institute of Technology (MIT)." MIT Facebook. Accessed October 24, 2018. https://www.facebook.com/MITnews/.

Massachusetts Institute of Technology (MIT)Verified Account. "Massachusetts Institute of Technology (MIT) (@MIT)." Twitter. October 24, 2018. Accessed October 24, 2018. https://twitter.com/MIT?ref_src=twsrc ${ }^{\wedge}$ google|twcamp^serp|twgr^author.

"MIT (@mitpics)• Instagram Photos and Videos." Instagram. Accessed October 24, 2018. https://www.instagram.com/mitpics/?hl=en.

Morse, Robert, Matt Mason, and Eric Brooks. "Best Colleges Ranking Category Definitions." U.S. News \& World Report. Accessed November 01, 2018. https://www.usnews.com/education/best-colleges/articles/ranking-category-definitions.

(C) 2018 Patrick R. Goncalves M.S.

This open access article is licensed under a Creative Commons Attribution: Non-Commercial license. DOI: JMCHE/v1i102 
Morse, Robert, and Eric Brooks. "Best Colleges Ranking Criteria and Weights." U.S. News \& World Report. Accessed October 01, 2018. https://www.usnews.com/education/bestcolleges/articles/ranking-criteria-and-weights.

Morse, Robert, Alexis Krivian, and Elizabeth Martin. "How U.S. News Calculated the Best Global Universities Rankings." U.S. News \& World Report. Accessed October 29, 2018. https://www.usnews.com/education/best-global-universities/articles/methodology.

"Northeastern University." Northeastern University Facebook. Accessed October 24, 2018. https://www.facebook.com/northeastern/.

"Northeastern University (@northeastern)• Instagram Photos and Videos." Instagram. Accessed October 24, 2018. https://www.instagram.com/northeastern/?hl=en.

PricewaterhouseCoopers LLP, comp. Annual Financial Report 2017. Report. Treasury Department, Tufts University. Medford, MA: Tufts University. 1-41.

PricewaterhouseCoopers LLP, comp. Annual Financial Report 2016-2017. Report. Treasury Department, University of Pennsylvania. Philadelphia, PA: University of Pennsylvania, 2017. $1-77$.

PricewaterhouseCoopers LLP, comp. Boston College: Consolidated Financial Statements May 31, 2018 and 2017. Report. Treasury Department, Boston College. Chestnut Hill, MA: Boston College, 2018. 1-19.

PricewaterhouseCoopers LLP, comp. California Institute of Technology Financial Statements For the Years Ended September 30, 2017 and 2016. Report. Treasury Department, California Institute of Technology. Pasedena, CA: California Institute of Technology, 2017. 1-36.

PricewaterhouseCoopers LLP, comp. Financial Report 2017. Report. Treasury Department, University of Washington. Seattle, WA: University of Washington, 2017. 1-48.

PricewaterhouseCoopers LLP, comp. Financial Report 2017-2018 Yale University. Report. T, Yale University. New Haven, CT: Yale University, 2018. 1-62.

PricewaterhouseCoopers LLP, comp. FINANCIAL REPORT FISCAL YEAR 2017. Report. Treasury Department, Harvard University. Cambridge, MA: Harvard University, 2017. 1-45.

(C) 2018 Patrick R. Goncalves M.S.

This open access article is licensed under a Creative Commons Attribution: Non-Commercial license. DOI: JMCHE/v1i102 
Vol 1 Issue 1 (2018)

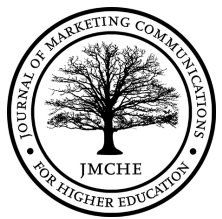

PricewaterhouseCoopers LLP, comp. MIT REPORT OF THE TREASURER 2017. Report. Treasury Department, Massachusetts Institute of Technology. Cambridge, MA: MIT, 2017. $1-50$.

PricewaterhouseCoopers LLP, comp. Northeastern University Consolidated Financial Statements June 30, 2017 and 2016. Report. Treasury Department, Northeastern University. Boston, MA: Northeastern University, 2017. 1-28.

PricewaterhouseCoopers LLP, comp. Report of the Treasurer 2016-2017. Report. Treasury Department, Princeton University. Princeton, NJ: Princeton University, 2017. 1-52.

PricewaterhouseCoopers LLP, comp. Reports and Financial Statements for the Year Ended 31 July 2017. Report. Treasury Department, University of Cambridge. Cambridge, England: University of Cambridge, 2017. 1-116.

PricewaterhouseCoopers LLP, comp. Stanford University Annual Financial Report August 31, 2017 and 2016. Report. Treasury Department, Stanford University. Stanford, CA: Stanford University, 2017. 1-99.

PricewaterhouseCoopers LLP, comp. The Trustees of Columbia University in the City of New York Consolidated Financial Statements June 30, 2018 and 2017. Report. Treasury Department, Columbia University. New York, NY: Columbia University, 2018. 1-40.

PricewaterhouseCoopers LLP, comp. Worcester Polytechnic Institute Consolidated Financial Statements June 30, 2017 and 2016. Report. Treasury Department, Worcester Polytechnic Institute. Worcester, MA: Worcester Polytechnic Institute, 2017. 1-29.

"Princeton University." Princeton University Facebook. Accessed October 29, 2018. https://www.facebook.com/PrincetonU/.

"Princeton University (@princeton)• Instagram Photos and Videos." Instagram. Accessed October 29, 2018. https://www.instagram.com/princeton/.

"Stanford University." Stanford University Facebook. Accessed October 29, 2018. https://www.facebook.com/stanford/.

"Stanford University (@stanford) • Instagram Photos and Videos." Instagram. Accessed October 29, 2018. https://www.instagram.com/stanford/?hl=en.

(C) 2018 Patrick R. Goncalves M.S.

This open access article is licensed under a Creative Commons Attribution: Non-Commercial license. DOI: JMCHE/v1i102 
"The University of Chicago." The University of Chicago Facebook. Accessed October 29, 2018. https://www.facebook.com/uchicago/.

"The University Of Chicago (@uchicago)・ Instagram Photos and Videos." Instagram. Accessed October 29, 2018. https://www.instagram.com/uchicago/?hl=en.

"The University of Oxford (@oxford_uni)・Instagram Photos and Videos." Instagram. Accessed October 29, 2018. https://www.instagram.com/oxford_uni/?hl=en.

"Tufts University." Tufts University Facebook. Accessed October 24, 2018. https://www.facebook.com/tuftsu/.

"Tufts University (@tuftsuniversity)• Instagram Photos and Videos." Instagram. Accessed October 24, 2018. https://www.instagram.com/tuftsuniversity/?hl=en.

"UC Berkeley." UC Berkeley Facebook. Accessed October 29, 2018. https://www.facebook.com/UCBerkeley/.

"UC Berkeley (@ucberkeley)• Instagram Photos and Videos." Instagram. Accessed October 29, 2018. https://www.instagram.com/ucberkeley/?hl=en.

"UMass (@uofmass)• Instagram Photos and Videos." Instagram. Accessed October 24, 2018. https://www.instagram.com/uofmass/.

University, Brandeis. "Brandeis University (@BrandeisU)." Twitter. October 24, 2018. Accessed October 24, 2018.

https://twitter.com/BrandeisU?ref_src=twsrc ${ }^{\wedge}$ google|twcamp ${ }^{\wedge} \operatorname{serp} \mid \operatorname{twgr}^{\wedge}$ author.

University, Clark. "Clark University (@ClarkUniversity)." Twitter. October 24, 2018. Accessed October 24, 2018.

https://twitter.com/ClarkUniversity?ref_src=twsrc ${ }^{\wedge}$ google $\mid$ twcamp ${ }^{\wedge} \operatorname{serp} \mid \operatorname{twgr}^{\wedge}$ author.

"University of Al Quaraouyine (website)." University of Al Quaraouiyine. Accessed November 4, 2018. http://uaq.ma/.

UNIVERSITY OF CALIFORNIA, BERKELEY Annual Financial Report 2016-17. Report. Treasury Department, University of California, Berkeley. Berkeley, CA: University of California, Berkeley, 2017. 1-27

(C) 2018 Patrick R. Goncalves M.S.

This open access article is licensed under a Creative Commons Attribution: Non-Commercial license. DOI: JMCHE/v1i102 
"University of Cambridge." University of Cambridge Facebook. Accessed October 29, 2018. https://www.facebook.com/cambridge.university/.

"University of Cambridge (@cambridgeuniversity) • Instagram Photos and Videos." Instagram. Accessed October 29, 2018. https:/www.instagram.com/cambridgeuniversity/?hl=en.

"University of Massachusetts." UMass Facebook. Accessed October 24, 2018. https://www.facebook.com/UniversityofMassachusetts/.

"University of Oxford." University of Oxford Facebook. Accessed October 29, 2018. https://www.facebook.com/the.university.of.oxford/.

"University of Pennsylvania." University of Pennsylvania Facebook. Accessed October 29, 2018. https://www.facebook.com/UnivPennsylvania/.

"University of Pennsylvania (@uofpenn) • Instagram Photos and Videos." Instagram. Accessed October 29, 2018. https://www.instagram.com/uofpenn/?hl=en.

"University of Washington." University of Washington Facebook. Accessed October 29, 2018. https://www.facebook.com/UofWA/.

"University of Washington (@uofwa) • Instagram Photos and Videos." Instagram. Accessed October 29, 2018. https://www.instagram.com/uofwa/?hl=en.

"WORCESTER POLYTECHNIC INST. (@wpi) • Instagram Photos and Videos." Instagram. Accessed October 24, 2018. https:/www.instagram.com/wpi/?hl=en.

"Worcester Polytechnic Institute (WPI)." WPI Facebook. Accessed October 24, 2018. https://www.facebook.com/wpi.edu/.

"World University Rankings." Times Higher Education (THE). November 30, 2018. Accessed October 29, 2018. https://www.timeshighereducation.com/world-university-rankings.

"Yale (@yale)• Instagram Photos and Videos." Instagram. Accessed October 29, 2018. https://www.instagram.com/yale/?hl=en.

"Yale University." Yale University Facebook. Accessed October 29, 2018. https://www.facebook.com/YaleUniversity/.

(C) 2018 Patrick R. Goncalves M.S.

This open access article is licensed under a Creative Commons Attribution: Non-Commercial license. DOI: JMCHE/v1i102 